\title{
PENDAMPINGAN MATERI IPA TERPADU UNTUK KOMPETISI SAINS MADRASAH DI MTS MAARIF NU 2 SUTOJAYAN
}

\author{
Marinda Sari Sofiyana \\ Program Studi Pendidikan Biologi , Fakultas Keguruan dan Ilmu Pendidikan \\ Universitas Islam Balitar \\ Email : sarisofiyana@gmail.com
}

\begin{abstract}
ABSTRAK
MTs Maarif NU 2 Sutojayan Blitar merupakan sekolah yang telah memulai pembimbingan secara intens untuk siswa-siswa unggul di bidang IPA terintegrasi. Pendampingan ini merupakan hasil kerjasama pihak sekolah dengan tim pengabdian. Pengabdian terdiri dari tiga tahap yaitu persiapan, pendampingan, dan evaluasi. Persiapan diawali dengan observasi berupa wawancara pada guru. Pendampingan dilakukan intensif setiap hari Senin hingga Jumat selama 2 jam. Setiap pertemuan diisi dengan penguatan materi dan latihan soal. Evaluasi dilakukan bersama guru bidang studi untuk refleksi dan peningkatan kegiatan di pengabdian selanjutnya.
\end{abstract}

Kata Kunci: Pendampingan, IPA Terpadu, KSM

\section{PENDAHULUAN}

Kompetensi Sains Madrasah (KSM) merupakan kegiatan yang diselenggarakan oleh Kementerian Agama Republik Indonesia. Kegiatan ini bertujuan untuk membangun semangat berkompetisi sains bagi siswa madrasah. Pada tahun 2020 KSM dilaksanakan secara daring (online). Hal ini karena kondisi pandemi yang terjadi tidak hanya di Indonesia, namun juga mewabah di seluruh dunia.

KSM mempunyai kelebihan dibandingkan dengan kompetisi lainnya. KSM memadukan nilai-nilai sains dengan nilai nilai keislaman. Integrasi kedua ilmu tersebut meliputi soal sains yang dipadukan dengan konteks di dalam Al Quran. Selain itu, soal-soal dalam KSM juga menggali konsep yang ada di dalam Islam. Integrasi ini bertujuan untuk mensejajarkan siswa siswi madrasah dengan siswa siswi di sekolah umum.

MTs Maarif NU 2 Sutojayan telah memulai pembimbingan intens untuk siswa-siswa yang memiliki hasil belajar yang baik. Pembimbingan KSM merupakan kerjasama pihak sekolah dengan tim pengabdian. Guru madrasah kesulitan beradaptasi dengan soal-soal olimpiade. Oleh karena itu, perlu adanya pendampingan terhadap penyelesaian masalah Ilmu Pengetahuan Alam (IPA) yang terbagi ke dalam materi biologi dan fisika. Strategi penyelesaian masalah 
diperlukan untuk menunjang siswa dalam mengikuti berbagai ajang kompetisi di bidang IPA.

\section{METODE PELAKSANAAN}

Metode pelaksanaan dari kegiatan pemantapan materi Kompetisi Sains Madrasah Online (KSMO) ini terdiri dari tiga tahap. Kegiatan ini dimulai dari kegiatan persiapan, kegiatan pendampingan, dan evaluasi. Adapun uraian dari masing-masing kegiatan adalah sebagai berikut.

1. Persiapan

Kegiatan persiapan ini diawali dengan kegiatan observasi guna mengetahui kondisi di sekolah berkaitan dengan kegiatan pendampingan KSMO. Registan persiapan ini juga dilakukan denga kegiatan wawancara terhadap pihak sekolah yaitu kepala sekolah dan guru bidang studi. Hasil wawancara menunjukkan siswa kesulitan menganalisis soal soal KSM karena belum terbiasa latihan mengerjakan soal KSM. Tim pengabdian melakukan diskusi internal dan mengkaji literatur guna membahas solusi yang digunakan untuk membantu permasalahan yang ada di sekolah. Diskusi berlanjut dengan penyusunan jadwal kegiatan dan materi yang akan dilakukan selama pendampingan.

2. Pendampingan

Tim melakukan pendampingan setiap hari Senin-Jumat selama 2 jam. Pendampingan dimulai dengan pembahasan singkat materi dan latihan soal KSM.

3. Evaluasi

Kegiatan implementasi selalu diikuti tim pengabdian dengan kegiatan evaluasi guna mengatasi kendala yang terjadi. Selain kegiatan evaluasi, kegiatan selanjutnya yang dilakukan oleh tim pengabdian adalah refleksi untuk keterlaksanaan kegiatan. Refleksi dilakukan setelah semua kegiatan berjalan, mulai dari perencanaan sampai dengan implementasi. Kegiatan refleksi ini dilakukan oleh tim pengabdian beserta dengan guru bidang studi dengan metode tanya jawab dan diskusi. Kegiatan ini dilakukan guna mengetahui apa saja yang terjadi pada saat pelaksanaan berlangsung.

\section{HASIL DAN PEMBAHASAN}

Kegiatan pendampingan Kompetisi Sains Madrasah (KSM) merupakan bentuk pengabdian telah 
terlaksana dengan baik. Kegiatan ini dilaksanakan pada Setiap hari aktif (Senin - Jumat). Adapun rincian waktu pelaksanaan pada masing-masing pertemuan ditunjukkan pada Tabel 1 . Masing-masing pertemuan berlangsung selama 2 jam (09.30-11.30). Setiap kegiatan diawali dengan pemberian materi sekitar 30 menit dan dilanjutkan dengan pembahasan soal-soal dan diskusi. Pembelajaran melalui diskusi dan tanya jawab interaktif dapat digunakan untuk memperkuat pemahaman konsep siswa (Ariyanti et al. 2019). Setelah penyampaian singkat materi, kegiatan dilanjutkan dengan pembahasan soal-soal KSM Tahun 2017, 2018, dan 2019. Soal terdiri dari 40 soal pilihan ganda. Soal biologi sebanyak 20 soal pilihan ganda, dan soal fisika sebanyak 20 soal pilihan ganda. Jenis pembinaan yang baik adalah program pembinaan dengan struktur $30 \%$ pemantapan teori, $50 \%$ latihan soal, dan $20 \%$ wawancara atau moderasi (Siregar 2017). Metode yang sama juga dilakukan oleh Fauzi dan Ewisahrani (2019).

Pendampingan juga dapat meningkatkan minat belajar siswa dalam bidang IPA. Intuisi juga dapat ditumbuhkan yang dapat dilihat dari adaptasi siswa yang cepat terhadap soal yang berbeda. Selama kegiatan berlangsung, respon siswa cukup baik. Hal ini dapat dilihat dari siswa yang awalnya pasif menjadi aktif bertanya tentang konsep konsep biologi maupun fisika. Selain itu, siswa bersemangat dalam mengikuti setiap pertemuan. Hambatan kecil yang dialami saat kegiatan adalah tidak lengkapnya jumlah siswa yang datang dikarenakan siswa yang bersangkutan sedang sakit.

Tabel 3 Uraian kegiatan pendampingan Kompetisi Sains Madrasah

\begin{tabular}{|c|c|c|}
\hline No & Tanggal & Materi \\
\hline 1 & 3 Agustus 2020 & $\begin{array}{l}\text { Makhluk hidup dan Organisasi } \\
\text { Kehidupan }\end{array}$ \\
\hline 2 & 4 Agustus 2020 & $\begin{array}{r}\text { Keanekaragaman dan } \\
\text { Klasifikasi Makhluk Hidup }\end{array}$ \\
\hline 3 & 5 Agustus 2020 & Ekologi \\
\hline 4 & 6 Agustus 2020 & Struktur dan Fungsi Tumbuhan \\
\hline 5 & 7 Agustus 2020 & $\begin{array}{l}\text { Pemahaman pada Vertebrata } \\
\text { dan Invertebrata }\end{array}$ \\
\hline 6 & 10 Agustus 2020 & Genetika \\
\hline 7 & 11 Agustus 2020 & Bioteknologi \\
\hline 8 & 12 Agustus 2020 & Pengukuran \\
\hline 9 & 13 Agustus 2020 & Energi \\
\hline
\end{tabular}




\begin{tabular}{ccc}
\hline 10 & 14 Agustus 2020 & Gerak dan gaya \\
11 & 17 Agustus 2020 & Fluida \\
12 & 18 Agustus 2020 & Getaran, gelombang, dan bunyi \\
13 & 19 Agustus 2020 & Cahaya dan Optika \\
14 & 20 Agustus 2020 & Zat dan Kalor \\
15 & 21 Agustus 2020 & Kelitrikan dan kemagnetan; \\
\end{tabular}

Setelah dilakukan refleksi kegiatan, diharapkan pada kegiatan berikutnya dilaksanakan tes tertulis untuk mengetahui pemahaman siswa (Randjawali 2020). Selain itu, perlu adanya produk hasil pendampingan dan pembimbingan KSM berupa modul materi (Rosyadi et al. 2018; Wijayanti 2020) Olimpiade IPA Terintegrasi. Kegiatan yang sama hendaknya juga dilakukan secara rutin (Maulana \& Mutmainah 2018) agar siswa terbiasa mengerjakan soal-soal di dalam kompetisi dan dapat meningkatkan rangking siswa di KSM (Erfan et. al. 2019). Pembelajaran juga dapat ditambahkan menggunakan Problem Posing untuk meningkatkan daya kritis dan kreativitas siswa (Sungkono et al. 2021). Hal ini dikarenakan persaingan KSM di tingkat madrasah sangat ketat (Wibowo et al. 2018). Kegiatan pendampingan juga perlu dilakukan kepada guru bidang studi agar guru mandiri mendampingi siswanya (Rachmawati 2014; Prawoto et. al. 2019; Zulhaenah \& Nurdian 2020).

\section{KESIMPULAN}

Kesimpulan pada kegiatan pendampingan ini berjalan baik sesuai dengan tujuan yang sudah ditetapkan. Kegiatan ini terdiri dari 1) Persiapan; 2) Pendampingan; 3) Evaluasi. Hasil yang diperoleh adalah hasil catatan pendampingan.

Saran yang disampaikan dari hasil kegiatan pengabdian ini adalah perlu kegiatan intensif terkait dengan pendampingan siswa. Siswa harus lebih banyak latihan soal-soal baik soal KSM ataupun soal olimpiade lainnya. Untuk kegiatan selanjutnya diharapkan ada produk yang dihasilkan berupa modul Kompetisi Sains Madrasah bidang IPA terintegrasi. Pendampingan juga perlu dilakukan kepada guru agar guru mandiri dalam mendampingi siswa.

\section{DAFTAR PUSTAKA}

Ariyanti G, Rahajeng R, Rahabistara A. 2019. Pembinaan olimpiade sains melalui pemberdayaan klub matematika dan IPA bagis siswa SMP di Kota Madiun. Jurnal Abdimas BSI 2 (2): 350-358.

Erfan M, Ratu T, Yahya F, Walidain SN, 
Fitriyanto S. 2019. Pendampingan persiapan Olimpiade Sains Nasional (OSN) tingkat kabupaten bagi siswa SMA Negeri 4 Sumbawa. Jurnal Pendidikan dan Pengabdian Masyarakat 2 (1): 114-119.

Fauzi A, Ewisahrani. 2019. Pendampingan peningkatan penyelesaian soal berbasis masalah pada Siswa SMKN 2 Bima. Abdi Masyarakat 1 (2): 6-9.

Maulana F, Mutmainah S. 2018. Pembinaan guru MTs Maarif NU 6 Taman Negeri menghadapi Kompetisi Sains Madrasah (KSM). Lumbung Inovasi (Jurnal Pengabdian Kepada Masyarakat IKIP Mataram 3 (1): 41-46.

Prawoto BP, Sulaiman R, Savitri D, Fardah DK. 2019. Pelatihan pendamping olimpiade matematika SMP Kabupaten Tulungagung. Jurnal ABDI 21-24.

Rachmawati DO. 2014. Pembinaan Olimpiade Sains Nasional (OSN) fisika SMA di Kecamatan Mengwi. Seminar Nasional FMIPA Undiksha IV.

Rosyadi AAP, Susanti RD, Dintarini M. 2018. IbM pendampingan dan pembimbingan olimpiade matematika berbasis strategi pemecahan masalah Polya pada siswa SMK Muhammadiyah 2 Malang. Jurnal Pengabdian Masyarakat Berkemajuan 2 (1): 22-26.
Randjawali E. 2020. Pendampingan persiapan olimpiade fisika tingkat kabupaten Sumba Timur bagi Siswa Sekolah Menengah Atas. Amal Ilmiah: Jurnal Pengabdian Kepada Masyarakat 2 (1): 22-27.

Siregar TJ. 2017. Pembinaan olimpiade matematika SMA Swasta Namira Islamic School Medan. Jurnal Pengabdian kepada Masyarakat 1 (1): 10-13.

Sungkono S, Riyanti A, Yanasari TL. 2021. Penerapan model pembelajaran Problem Posing untuk meningkatkan daya kritis dan kreativitas siswa SMP. Jurnal Al Iklhas 6 (2): 382-392.

Wibowo A, Muslihasari A, Oktiningrum W. 2018. Program pendampingan Kompetisi Sains Madrasah tahun 2018 pada kelompok kerja kepala Madrasah Ibtidaiyah Kecamatan Bantur Kabupaten Malang. At Tamkin Jurnal pengabdian Kepada Masyarakat 1 (1): 1-12.

Wijayanti PS. 2020. Pengembangan modul matematika dan pelatihan penyelesaian soal bertipe olimpiade untuk tingkat SMA. Community Development Journal 1 (3): 354-358.

Zulhaenah K, Nurdian Y. 2020. Pendampingan dan peningkatan kecakapan guru dalam inovasi pembelajaran daring di tengah pandemi Covid-19. Jurnal Pengabdian Al-Iklhlas 6 (2): 238248. 